American Journal of Animal and Veterinary Sciences 4 (1): 6-13, 2009

ISSN 1557-4555

(C) 2009 Science Publications

\title{
Reactive Nitrogen Intermediates Production by Macrophages of Mycobacterium bovis- Infected Goats and Supplemented with Dyhidroxyvitamin D3 in vivo
}

\author{
${ }^{1}$ Aurora Martinez-Romero, ${ }^{2}$ Jose Luis Ortega-Sanchez, ${ }^{2}$ Jose Ramon Hernandez-Salgado, \\ ${ }^{3}$ Margarita Yolanda Mendoza-Ramos, ${ }^{3}$ Rafael Rodriguez-Martinez, ${ }^{6}$ Maribel Cervantes-Flores, \\ ${ }^{5}$ Joel Lopez-Perez, ${ }^{6}$ Norma Urtiz-Estrada, ${ }^{4}$ Miguel Arenas-Vargas and ${ }^{3}$ Raul Villegas-Viscaino \\ ${ }^{1}$ Department of Posgrade and Investigation, Faculty of Chemical Sciences, Gomez Palacio Unit, \\ Juarez University of the State of Durango, Mexico \\ ${ }^{2}$ Regional Unit University of Arid Zones, \\ Chapingo Autonomy University, Bermejillo, Durango, Mexico \\ ${ }^{3}$ Department of Veterinary Medical Science, \\ Autonomy Agrarian University Antonio Narro, Lagoon Unit, Torreon, Coahuila, Mexico \\ ${ }^{4}$ Department of Agricultural and Animal Production, \\ Autonomy Metropolitan University, Xochimilco Unit, DF, Mexico \\ ${ }^{5}$ Center of Innovation and Educational Development, Center of Studies Justo Sierra, \\ Surutato, Badiraguato, Sinaloa, Mexico \\ ${ }^{6}$ Department of Posgrade and Investigation, Faculty of Chemical Sciences, Durango Unit, \\ Juarez University of the State of Durango, Mexico
}

\begin{abstract}
Problem statement: Tuberculosis (TB) remains one of the world's major health problems. To evaluate in vivo indices of cellular sensitization, antigen-induced Reactive Nitrogen Intermediates (RNI) responses by blood mononuclear cells from Mycobacterium bovis BCG-infected goats supplemented with 1, 25 dyhidroxyvitamin D3 [1, 25-(OH) 2 D3]. Approach: An experimental, longitudinal and comparative study was planned. Twelve animals of goat cattle 20-to 24-month-old sannen selected themselves. Five samplings were made, previous to the inoculation (zero d), 3, 7, 14 and $21 \mathrm{~d}$ after applying the treatments. The mononuclear cells by the Ficoll-hypaque method were obtained. The RNI, nitrites and nitrates $\left(\mathrm{NO}_{2}^{-}\right.$and $\left.\mathrm{NO}_{3}^{-}\right)$were quantified by Enzyme-Linked Immunosorbent Assay (ELISA). Results: The treatment with the 1, 25(OH) $)_{2} \mathrm{D} 3$ stimulated the $\mathrm{NO}_{3}{ }^{-}$ synthesis indicating, that by itself it is a good modulador of the micobacterial replication and in the treatment with $M$. bovis-BCG vaccine increased as a result to the treatment with $1,25(\mathrm{OH})_{2} \mathrm{D} 3$. The exhibition to $M$. bovis-BCG vaccine with the treatment with $1,25(\mathrm{OH})_{2} \mathrm{D} 3$ was able to increase answer $\mathrm{NO}_{3}{ }^{-}$in exposed animals. Conclusion: The $1,25(\mathrm{OH})_{2} \mathrm{D} 3$ stimulated in vivo the production of RNI in goats exposed to $M$. bovis BCG vaccine.
\end{abstract}

Key words: $M$. bovis-BCG vaccine, 1,25 dihydroxyvitamin D3, nitrites, nitrates, goats

\section{INTRODUCTION}

Tuberculosis (TB) remains one of the world's major health problems and the leading cause of death from a single infectious agent called Mycobacterium tuberculosis, the primary causative agent ${ }^{[1]}$. TB is a zoonotic disease that often becomes chronic with high rate of recurrence. The World Health Organization has declared TB a global emergency, the first disease so designated $M$. tuberculosis infects a third of the worldwide population to the year, in spite of the efforts of public health to control their dissemination ${ }^{[2,3]}$, the majority of such infections remain clinically latent ${ }^{[4]}$, the pathogeneicity include its ability to resist the harsh environment of the host macrophage and to persist within immunocompetent hosts ${ }^{[5]}$. The entry and survival of Mycobacterium in macrophages are central to the pathogenesis of TB. In addition, the ability of the macrophage to resist the growth of the microorganisms is dependent on the activation state of the macrophage. One essential component of tubercular host defense includes Nitric Oxide (NO). Waters, Palmer et al. ${ }^{[12]}$

Corresponding Author: Aurora Martinez-Romero, Department of Posgrade and Investigation, Faculty of Chemical Sciences, Gomez Palacio Unit, Juarez University of the State of Durango, Mexico 
determined that there are two essential components of tubercular host defense include $\mathrm{NO}$ and Tumor Necrosis Factor alpha (TNF- $\alpha)$. Stimulation of inducible NO Synthase (iNOS) in macrophages and subsequent generation of RNI are potent mechanisms for mycobacterial killing ${ }^{[6,7]}$. Interestingly, it has been associated with risk of dissemination and mortality the absence of iNOS $^{[8]}$. Furthermore, it has been used, NO inhaled like treatment for $\mathrm{TB}^{[9]}$. Therefore, iNOS synthesis is essential for maintaining stationary-level infection $^{[10]}$, has been investigated iNOS presence in biopsies exhibiting dermal nerves from patients with untreated leprosy ${ }^{[11]}$. NO is readily produced by Mycobacterium-induced Peripheral Blood Mononuclear Cells (PBMC) from M. bovis-infected cattle. NO responses play an important role in organism and host defense. NO metabolism of the host is markedly altered in all infections. In recent reports, NO concentrations were found to be increased in culture supernatants and this is gaining wide acceptance for use in TB diagnosis $^{[12]}$. Evaluation of NO response may prove useful for diagnosis of bovine TB, nitrite $\left(\mathrm{NO}_{2}{ }^{-}\right)$is the stable oxidation product of $\mathrm{NO}$ and the amount of $\mathrm{NO}_{2}^{-}$ within culture supernatants is indicative of the amount of NO produced by cells in culture ${ }^{[12]}$. The $1,25-$ $(\mathrm{OH})_{2} \mathrm{D} 3$ is a powerful stimulus for the production of NO by macrophages, which are indicative of the defense of the host against the $\mathrm{TB}^{[13]}$. Has been considered that the active principle of vitamin $\mathrm{D}$, the 1 , 25 Dihydroxyvitamin D3 [1,25-(OH $\left.)_{2} \mathrm{D} 3\right]$, it has turned to be a powerful regulator of the immune response. Additionally, it has been observed that 1,25-(OH) $)_{2} \mathrm{D} 3$ suppresses to the growth of Mycobacterium in the macrophages through a dependent mechanism of $\mathrm{NO}^{[14]}$. An important point is that $25-\mathrm{OH}-\mathrm{D} 3$ is turned to $1,25-(\mathrm{OH})_{2} \mathrm{D} 3$ within the macrophage and the proportion of conversion increases within the alveolar macrophages and in followed human monocites of the stimulation with IFN- $\gamma^{[15,16]}$, it is probable that the $1,25-$ $(\mathrm{OH})_{2} \mathrm{D} 3$ triggers a dependent mechanism of NO that increases the destruction of Mycobacterium ${ }^{[17,18]}$. The M. bovis Bacillus Calmette-Guerin (BCG) vaccine, an attenuated strain of $M$. bovis, was developed for control of human TB more than 70 years ago and is still the only TB vaccine available. The protection against TB requires the induction of Th1 immune response, but studies with new-born animal have shown that they preferentially develop Th2-Type responses following immunization and are deficient in Th1 responses ${ }^{[19]}$. As a result, the bacterial transcription changes of the Th1mediated immune response are likely induced, directly or indirectly, by NO generated by infected macrophages ${ }^{[20]}$. BCG vaccination at birth induced a high level of immunity and that the sensitization of very young animals to antigens of environmental mycobacteria by 6 weeks of age did not affect the effectiveness of $\mathrm{BCG}^{[19]}$. Characteristic changes in RNI metabolism, are an integral part of the cellular immune assays. Weatherby et $a l .^{[21]}$, have confirmed that macrophages are among the first cells in innate resistance to intracellular microbial pathogens, they have been determining that the cytokines gammaInterferon (IFN- $\gamma$ ), Granulocyte-Macrophage ColonyStimulating Factor (GM-CSF) and TNF- $\alpha$ activate macrophages to resist the growth of intracellular pathogens during the improvement in the production of antimicrobials molecules, including the RNI and the Reactive Oxigen Intermediates (ROI $)^{[8,21]}$, proinflammatory cytokines such as interleukin (IL-12) play critical roles in the induction of host resistance to Mycobacterium $^{[22]}$. In addition, the activated macrophages can turn the L-arginina to $\mathrm{NO}_{2}{ }^{-}$in the presence of the iNOS enzyme, with the development of a cytotoxic activity against tumor cells ${ }^{[23]}$ and in front of bacterial infections ${ }^{[24]}$. The RNI are protective agents in infectious processes as VIH, Helicobacter pilori, M. tuberculosis, malaria and infections of respiratory tract and urinary, also have been observed in a great diversity of autoimmune diseases and chronic inflammatory diseases ${ }^{[25]}$. Additionally, as an end product in the reaction of iNOS has been determined the presence of nitrotyrosine in lung and tissues several, finding very similar levels ${ }^{[26]}$. Nevertheless, the targets of RNI in Mycobacterium are unknown ${ }^{[27]}$. Different studies have raised that the exhibition to the $M$. bovis BCG vaccine alters the specific immune response, it causing an increase of the immune response mediated by Th1 cells and an stimulation of the immune response Th2. In addition, Flynn et al. ${ }^{[28]}$ demonstrated that Mycobacterium reactivation occurs if the production of Reactive Nitrogen Intermediates (RNI) is inhibited in a murine model of latency ${ }^{[28]}$. However, little is known about the role of these intermediates during latent infections. Different studies have been raised that the exhibition to the $M$. bovis BCG vaccine alters the specific immune response, it causing an increase of the immune response mediated by Th1 cells and a stimulation of the immune response Th2. In addition, Flynn et al. ${ }^{[28]}$ demonstrated that Mycobacterium reactivation occurs if the production of Reactive Nitrogen Intermediates (RNI) is inhibited in a murine model of latency ${ }^{[28]}$. However, little is known about the role of these intermediates during latent infections. It has been observed which in infections of $M$. bovis the 1 , $25-(\mathrm{OH})_{2} \mathrm{D} 3$ accelerates the specific production of and $\mathrm{RNI}^{[29]}$. But, it is necessary to consider the development 
of new investigations to clarify these discoveries. The aim of the present study was to quantify RNI production by macrophages from $M$. bovis-BCG infected goats supplemented with $1,25-(\mathrm{OH})_{2} \mathrm{D} 3$.

\section{MATERIALS AND METHODS}

Animals and immunizations: Twelve goats were 20-to 24-month-old sannen. They were maintained with a diet supplemented with grain; they were supplied with water ad libitum. Four treatments were carried out, control, supplemented with $M$. bovis BCG vaccine (Pasteur Merieux ${ }^{\circledR}$, Lyon France), 1, $25(\mathrm{OH}){ }_{2} \mathrm{D} 3$ and $M$. bovis BCG vaccine plus $1,25(\mathrm{OH}){ }_{2} \mathrm{D} 3$. Three goats were immunized by the intramuscular injection of $0.1 \mathrm{~mL}$ volumes of saline solution, three goats with $0.1 \mathrm{~mL}$ volumes of $M$. bovis BCG vaccine, three goats with $0.25 \mu \mathrm{g}$ de 1,25-(OH) ${ }_{2} \mathrm{D} 3$ (CALCITRIOL -alfa 25hihidroxicolicolecalcitrol GELDEX-GELPHARMA®) and three with $M$. bovis BCG vaccine plus $1,25(\mathrm{OH})_{2} \mathrm{D} 3$. Whole blood was collected from the jugular vein of antigen-primed goats. Samples of peripheral blood were collected in Vacutainer tubes (BD Vacutainer ${ }^{\mathrm{TM}} \mathrm{K}_{3}$ EDTA; Becton Dickinson, Franklin Lakes, NJ).

Peripheral Blood Mononuclear Cells (PBMC): Whole blood samples were collected and blood mononuclear cells were obtained immediately before challenge [day 0] and 3, 7, 14 and 21 days postchallenge. Whole blood was centrifuged at $3000 \times \mathrm{g}$ for $15 \mathrm{~min}$, after was separated leucocytes layer in a $15 \mathrm{~mL}$ screw cap polypropylene centrifuge tube (Corning® 430790). Mixtures containing goat blood were overlaid on Ficoll-Hypaque (Sigma ${ }^{\circledR}$ H8889 $\mathrm{d}=1.077 \mathrm{~g} \mathrm{~mL}^{-1}$ ) at a radio of $6 \mathrm{~mL}$ of calcium and magnesium free Phosphate Buffered Saline (PBS), it is designed to maintain a physiological $\mathrm{pH}$ in an open system, to $3 \mathrm{~mL}$ of Ficoll in a $15 \mathrm{~mL}$ polypropylene centrifuge tube. The resulting gradient was centrifuged at $1500 \times \mathrm{g}$ for $15 \mathrm{~min}$. Caprine PBMC were then collected, washed one time in PBS solution and suspended in RPMI 1640 medium supplemented ${ }^{[12]}$.

Cell viability: Viability of the samples was measured by trypan blue (derived from tolidine, that is, any of several isomeric bases, $\mathrm{C}_{14} \mathrm{H}_{16} \mathrm{~N}_{2}$, derived from toluene) dye exclusion method where the viable (unstained) cells were counted in a hemocytometer under a light microscope. Samples of at least three independent experiments were analyzed in duplicate ${ }^{[30]}$. The reactivity of trypan blue is based on the fact that the chromopore is negatively charged and does not interact with the cell unless the membrane is damaged. Therefore, all the cells which exclude the dye are viable. Trypan Blue Staining of Cells was Place $0.5 \mathrm{~mL}$ of a suitable cell suspension (dilute cells in complete medium without serum to an approximate concentration of $1 \times 10^{5}-2 \times 10^{5}$ cells $\mathrm{mL}^{-1}$ ) in a screw cap test tube, add $10 \mu \mathrm{L}$ of $0.4 \%$ Trypan Blue Stain. Mix thoroughly; allow standing $5 \mathrm{~min}$ at $15-30^{\circ} \mathrm{C}$ (room temperature). Fill a hemocytometer as for cell counting and under a microscope, observe if non-viable are stained and viable cells excluded the stain.

Cell culture: The wells of 24-well round-bottom microtiter plates (Corning Costar®24-well T-C Treated microplates, Individually Wrapped No. 3526) were seeded with $2 \times 10^{5}$ PBMC in a total volume of $200 \mu \mathrm{L}$ per well. The goat macrophage cell was obtained from a cell culture. The cells were cultured at $37^{\circ} \mathrm{C}$ in $5 \%$ carbon dioxide atmosphere in RPMI 1640 medium supplemented with $2 \mathrm{mM}$ L-glutamine, $25 \mathrm{mM}$ HEPES buffer, 100 units of penicillin $\mathrm{mL}^{-1}, 0.1 \mathrm{mg}$ of streptomycin $\mathrm{mL}^{-1}, 1 \%$ nonessential amino acids (Sigma), 2\% essential amino acids (MP Biomedicals®), $50 \mu \mathrm{M}$ 2-mercaptoethanol (Sigma) and 10\% (vol/vol) heat-inactivated fetal bovine serum ${ }^{[31]}$. The macrophages $\left(5 \times 10^{5}\right.$ cellsmL $\left.{ }^{-1}\right)$ were dispensed to sixwell plates, $2 \mathrm{~mL}^{-1}$ well. The cells were allowed to adhere for $48 \mathrm{~h}$, was removed the supernatant from adherent cells and were resuspended in cool PBS by scraping, the viability of the cells was assessed and the cell suspension was obtained in a microcentrifuge tube (Eppendorf Axygen $®)$, centrifuged (5 min, 1,500 rpm) to separate the cells from the PBS. The cells were suspended in an adequate cryoprotection it was constituted by $90 \%$ of fetal bovine serum and $10 \%$ of Di-Methyl-Sulfoxide (DMS) and later were stored at$70^{\circ} \mathrm{C}$ for the subsequent analyses. Sterilize DMSO was by filtration through a $0.2 \mu \mathrm{m}$ cellulose membrane and was stored in small quantities $(2 \mathrm{~mL})$.

Measurement of Reactive Nitrogen Intermediates (RNI): The RNI concentrations were obtained prior and after vaccination and challenge. RNI were measured spectrophotometrically as the stable metabolite $\mathrm{NO}_{2}^{-}$ according to the Griess method (1\% sulfanilamide and $0.1 \%$ naphthylethylenediamine dihydrochloride in $2 \%$ phosphoric acid) ${ }^{[32]}$. $\mathrm{NO}_{2}^{-}$and $\mathrm{NO}_{3}^{-}$optical densities were measurement with ELISA microplate reader (Organon Tecknika, Microwell system). Stock solutions of sodium nitrite and sodium nitrate (Baker) at $100 \mathrm{Mm}$ in phosphates buffer were stored at $4^{\circ} \mathrm{C}$. The solution of nitrate reductase (Sigma) at $2.5 \mathrm{U} \mathrm{mL}^{-1}$ and a mixture 
of NADPH (Sigma) at $1,67 \mathrm{mg} \mathrm{mL}^{-1}$ plus flavin adenine dinucleotide-FAD (Sigma) at $0.05 \mathrm{mg} \mathrm{mL}^{-1}$ in sterile desionized water were stored at $-20^{\circ} \mathrm{C}$. Prior to use, 1 volume of nitrate reductase was mixed 3 volumes of NADPH-FAD (enzyme mixture). The production of nitrite was quantified by comparing the results with absorbance of standard solutions of sodium nitrite. Samples of at least four independent experiments were analyzed in duplicate. The assay was performed in nonsterile 8-well plates. The samples (cell culture medium)were divided between two plates, one for measuring $\mathrm{NO}_{2}{ }^{-}$and the other for measuring $\mathrm{NO}_{3}{ }^{-}$in each one $50 \mu \mathrm{L}$ of sample were added plus $20 \mu \mathrm{L}$ of water for the measurement of $\mathrm{NO}_{2}^{-}$and $20 \mu \mathrm{l}$ of enzyme mixture for the measurement of $\mathrm{NO}_{3}{ }^{-}$after were incubated for $30 \mathrm{~min}$ at room temperature. Griess reagent $(100 \mathrm{ml}$ per well) was added and left for $5 \mathrm{~min}$ at room temperature and then the Optical Densities (ODs) in all plates were read at $620 \mathrm{~nm}$ (reference) and $540 \mathrm{~nm}$ (test) ${ }^{[32]}$. Nitrite concentrations were calculated directly from the nitrite standard curve. To determine nitrate concentration, OD nitrite was subtracted from OD nitrate before comparison with the nitrate standard curve. Medium alone was used to calculate the assay background level and this was subtracted from all data $^{[14]}$. In order to determine whether there was any association between nitrites or nitrates responses and protection against experimental infection with $M$. bovis, these RNI were measured at regular intervals during the vaccine trial.

Statistical method: A design at random with repeat measures in the periods was used completely ${ }^{[33]}$. The procedure that it was used was PROC MIXED (SAS, 1999). The used statistical model was the following one:

$$
\mathrm{Y}_{\mathrm{ijkl}}=\mu+\zeta_{\mathrm{i}}+\mathrm{C} \zeta_{\mathrm{j}(\mathrm{i})}+\mathrm{P}_{\mathrm{k}}+\zeta \mathrm{P}_{\mathrm{ik}}+\beta\left(\mathrm{x}_{\mathrm{i}} \cdot-\mathrm{x} . .\right)+\varepsilon_{\mathrm{ijkl}}
$$

Concentrations of nitrite were determined by comparison with a standard of sodium nitrite. All samples were assayed in duplicate (version 8.0; SAS Institute Inc., Cary, North, Carolina).

\section{RESULTS}

Differences were observed in the nitrites and nitrates responses (Fig. 1 and 2). Control animals $\mathrm{NO}_{2}{ }^{-}$

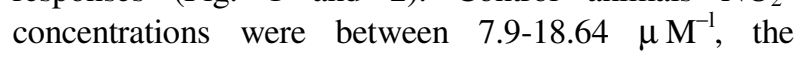
supplemented treatment with $M$. bovis BCG vaccine were $10.84-17.06 \mu \mathrm{M}^{-1}$, the next treatment $1,25(\mathrm{OH})_{2} \mathrm{D} 3$ were $13.93-25.38 \mu \mathrm{M}^{-1}$ and the last treatment $M$. bovis
BCG vaccine plus $1,25(\mathrm{OH})_{2} \mathrm{D} 3$ were $12.64-8.29 \mu \mathrm{M}^{-1}$. Control animals $\mathrm{NO}_{3}^{-}$concentrations were between 26.06-39.23 $\mu^{-1}$, the supplemented treatment with M. bovis BCG vaccine were 17.77-64.27 $\mu \mathrm{M}^{-1}$,

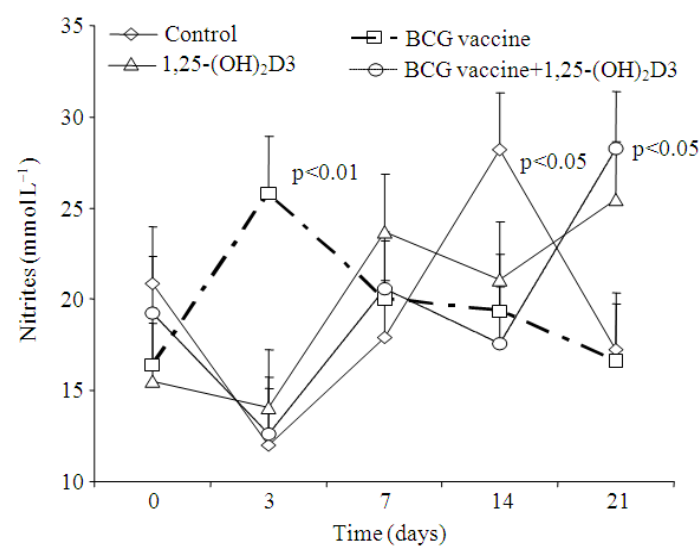

Fig. 1: Average of minimum squares and standard errors of the concentration of nitrites in cells culture (macrophages) when applying different treatments increased the answer of the immune system in goats. The measurement of nitrites was realized in $48 \mathrm{~h}$ cells culture. The measurements $(n=12)$ utilized in this analysis were from five points (prechallenge [day 0] and $3,7,14$ and 21 days postchallenge

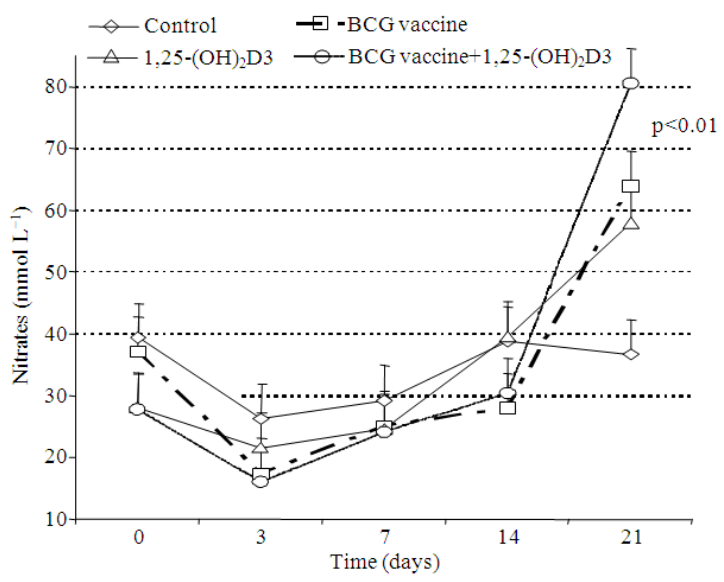

Fig. 2: Average of minimum squares and standard errors of the concentration of nitrates in cells culture (macrophages) when applying different treatments increased the answer of the immune system in goats. The measurement of nitrates was realized in $48 \mathrm{~h}$ cells culture. The measurements $(n=12)$ utilized in this analysis were from five points (prechallenge [day 0] and $3,7,14$ and 21 days postchallenge 
The next treatment $1,25(\mathrm{OH})_{2} \mathrm{D} 3$ were 20.9457.35 $\mu^{-1}$ and the last treatment $M$. bovis BCG vaccine plus $1,25(\mathrm{OH})_{2} \mathrm{D} 3$ were $16.41-80.94 \mu \mathrm{M}^{-1}$. The two groups vaccinated with BCG produced significantly higher mean peripheral blood $\mathrm{NO}_{2}{ }^{-}$and $\mathrm{NO}_{3}{ }^{-}$responses to $\mathrm{BCG}$ and $\mathrm{BCG}$ plus $1,25(\mathrm{OH})_{2} \mathrm{D} 3$ than those for the nonvaccinated group $(\mathrm{p}<0.05)$. The group vaccinated with $\mathrm{BCG}$ plus $1,25(\mathrm{OH})_{2} \mathrm{D} 3$ produced significantly higher mean $\mathrm{NO}_{3}{ }^{-}$response than those for the BCG only group $(\mathrm{p}<0.05)$. There were no significant differences between the mean $\mathrm{NO}_{2}^{-}$. The concentrations differences between $\mathrm{NO}_{2}^{-}$and $\mathrm{NO}_{3}{ }^{-}$ were considered significant at $(\mathrm{p}<0.01)$. However, the treatments effect was no significant $(p>0.9)$. The treatment with the $1,25(\mathrm{OH})_{2} \mathrm{D} 3$ stimulated the $\mathrm{NO}_{3}{ }^{-}$ synthesis indicating, that by itself it is a good modulador of the micobacterial replication and in the treatment with $M$. bovis-BCG vaccine increased as a result to the treatment with $1,25(\mathrm{OH})_{2} \mathrm{D} 3$. The exhibition to $M$. bovis-BCG vaccine with the treatment with $1,25(\mathrm{OH})_{2} \mathrm{D} 3$ was able to increase answer $\mathrm{NO}_{3}{ }^{-}$in exposed animals.

\section{DISCUSSION}

Vitamin D is known for its beneficial effects in diseases with strong Th1 responses, perhaps by altering Th1/Th2 balance in vivo ${ }^{[34]}$. The monocites ${ }^{[35]}$ and the dendritic cells ${ }^{[36]}$ express the receivers constituently of the $1,25(\mathrm{OH})_{2} \mathrm{D} 3$. However, has been observed that $1,25(\mathrm{OH})_{2} \mathrm{D} 3$ treatment inhibited chemokine-induced migration of $\mathrm{T}$ cells ${ }^{[37]}$. In this study, it was observed that $\mathrm{NO}_{3}{ }^{-}$concentration was significantly higher in animals with $M$. bovis-BCG plus $1,25(\mathrm{OH})_{2} \mathrm{D} 3$ compared with $\mathrm{NO}_{2}^{-}$concentration. In addition, an increase in the $\mathrm{NO}_{3}{ }^{-}$production was observed with the challenge to the alone $1,25(\mathrm{OH})_{2} \mathrm{D} 3$. Indicating with that it is a good regulate of the micobacterial replication. In addition to this asseveration, has been determined that the active metabolite of the vitamin $\mathrm{D}$ is the $1,25(\mathrm{OH})_{2} \mathrm{D} 3$, that is a powerful regulator of the immune response ${ }^{[38]}$. Interestingly, in a previous study was determined that it is possible that RNI and ROI can inhibit the bactericidal replication (bacteriostatic) but not eradicate the bacterium (bactericidal) ${ }^{[39]}$. This agrees with studies ${ }^{[40]}$ that demonstrated that the reactivation with $M$. tuberculosis happens if the RNI production is inhibited. The NO is a found unstable molecule in the biological systems and quickly is turned $\mathrm{NO}_{2}{ }^{-}$and $\mathrm{NO}_{3}{ }^{-}$. However, the amount of $\mathrm{NO}_{2}{ }^{-}$within culture supernatants is indicative of the amount of NO produced by cells in culture ${ }^{[12]}$. In this study, the supplemented animals with $M$. bovis BCG vaccine were 10.84-17.06 $\mu \mathrm{M}^{-1}$. In addition, other studies have demonstrated that between 34 and $241 \mathrm{nmol}$ of $\mathrm{NO}_{2}{ }^{-}$in culture supernatants of human peripheral blood monocytes infected with $M$. tuberculosis ${ }^{[41]}$ are generated. Has been considered that while most virulent strains of Mycobacterium are more susceptible to $\mathrm{RNI}^{[32]}$. The $\mathrm{NO}$ in the macrophages acts like a powerful microbicidal to destroy to the ingested microorganisms. We obtained a constant elevation of the concentration of $\mathrm{NO}_{3}{ }^{-}$to the course of the period of the study arriving at the 21 day to a concentration of $80.94 \mu \mathrm{M}^{-1}$. There are evidences of endogenous $\mathrm{NO}_{3}{ }^{-}$ production, especially in answer to inflammatory stimuli where the $\mathrm{NO}_{3}^{-}$production in vitro could be induced by the macrophages in the presence of lipopolysaccharide ${ }^{[42]}$. Therefore, it is deduced that the production of RNI in macrophages is essential for the defense of the host, mainly to exert bactericidal actions. In addition, it was demonstrated that the stimulation of iNOS in macrophages and the subsequent generation of RNI are powerful mechanisms to kill the Mycobacterium $^{[42]}$. Was reported that the first time that Mycobacterium induces mRNA for iNOS, iNOS protein, NO and peroxinitrite in human monocyte/macrophage cultures ${ }^{[31]}$. Moreover, Waters et $a l .{ }^{[12]}$, have investigated 49 cattle with no history of TB and infected with $M$. bovis, they reported that NO concentration was found to be significantly higher in control group than those of healthy animals and they concluded that NO concentrations were altered probably by the effects of some immunocytokines as host defense elements of organism during infection. However, in culture supernatants exists IFN- $\gamma$ that increased macrophage $\mathrm{NO}_{2}^{-}$production. In addition, IFN- $\gamma$ was found to be the critical mediator of NO production $^{[43]}$. Protective immunity against intracellular bacteria such as TB species depends on the interplay between various T-cell subsets and cytokines. Cellmediated immunity to $\mathrm{TB}$ is likely to include the production of cytokines that activate macrophages and lymphocytes for production of anti-tuberculosis activities. In this study we determined that $1,25(\mathrm{OH})_{2} \mathrm{D} 3$ therapy during acute TB had beneficial effects both clinically and in modulating the systemic humoral and cellular immune response for increased host defense. The present study is the first to assess the effectiveness of BCG administered to goats to induce immune responses and protection against challenge with virulent $M$. bovis.

\section{CONCLUSION}

In conclusion, the $1,25(\mathrm{OH})_{2} \mathrm{D} 3$ stimulates in vivo the production of RNI in goats exposed to $M$. bovis BCG vaccine. Clearly, the high RNI levels observed were associated with the increased of Th1-mediated 
immune response and can help to study of many antitubercular treatments. RNI diagnosis can provide new clues about the different clinical outcomes after Mycobacterium infection. Further studies are necessary to determine the importance of RNI in cases with tuberculosis.

\section{REFERENCES}

1. Harth, G. and M.A. Horwitz, 2003. Inhibition of mycobacterium tuberculosis glutamine synthetase as a novel antibiotic strategy against tuberculosis: Demonstration of efficacy in vivo. Infect. Immunol., 71: 456-464. DOI: 10.1128/IAI.71.1.456-464.2003

2. Tazi, L., J. El Baghdadi, S. Lesjean, C. Locht, P. Supply and M. Tibayrenc et al., 2004. Genetic diversity and population structure of mycobacterium tuberculosis in Casablanca, a Moroccan city with high incidence of tuberculosis. J. Clin. Microbiol., 42: 461-466. DOI: 10.1128/JCM.42.1.461466.2004

3. Giordano, T.P., H. Soini, L.D. Teeter, G.J. Adams, J.M. Musser and E.A. Graviss, 2004. Relating the size of molecularly defined clusters of tuberculosis to the duration of symptoms. Clin. Infect. Dis., 38: 10-16. DOI: 10.1086/380454

4. Choi, H.S., P.R. Rai, H.W. Chu, C. Cool and E.D. Chan, 2002. Analysis of nitric oxide synthase and nitrotyrosine expression in human pulmonary tuberculosis. Am. J. Respir. Crit. Care Med., 166: 178-186.

http://ajrccm.atsjournals.org/cgi/content/abstract/16 6/2/178

5. Firmani, M.A. and L.W. Riley, 2002. Reactive nitrogen intermediates have a bacteriostatic effect on mycobacterium tuberculosis in vitro. J. Clin. Microbiol., 40: 3162-3166. DOI: 10.1128/JCM.40.9.3162-3166.2002

6. MacMicking, J.D., R.J. North, R. LaCourse, J.S. Mudgett, S.K. Shah and C.F. Nathan, 1997. Identification of nitric oxide synthase as a protective locus against tuberculosis. Proc. Natl. Acad. Sci. USA., 94: 5243-5248. http://www.pnas.org/content/94/10/5243.abstract

7. Morris, K.R., R.D. Lutz, H.S. Choi, T. Kamitani, K. Chmura and E.D. Chan, 2003. Role of the NFkappaB signaling pathway and kappaB cisregulatory elements on the IRF-1 and iNOS promoter regions in mycobacterial lipoarabinomannan induction of nitric oxide. Infect. Immunol., 71: 1442-1452. DOI: 10.1128/IAI.71.3.1442-1452.2003
8. Chan, E.D., J. Chan and N.W. Schluger, 2001. What is the role of nitric oxide in murine and human host defense against tuberculosis?Current knowledge. Am. J. Respir. Cell. Mol. Biol., 25: 606-612. http://ajrcmb.atsjournals.org/cgi/content/abstract/25/5/606

9. Long, R., R. Jones, J. Talbot, I. Mayers, J. Barrie and M. Hoskinson et al., 2005. Inhaled nitric oxide treatment of patients with pulmonary tuberculosis evidenced by positive sputum smears. Antimicrob. Agents Chemother., 49: 1209-1212. DOI: 10.1128/AAC.49.3.1209-1212.2005

10. Jung, Y.J., L. Ryan, R. LaCourse and R.J. North, 2003. Increased interleukin-10 expression is not responsible for failure of $\mathrm{T}$ helper 1 immunity to resolve airborne mycobacterium tuberculosis infection in mice. Immunology, 109: 295-299. http://www.ncbi.nlm.nih.gov/pubmed/12757625

11. Schon, T., R. Hernandez-Pando, J. BaqueraHeredia, Y. Negesse, L.E. Becerril-Villanueva and J.C. Eon-Contreras et al., 2004. Nitrotyrosine localization to dermal nerves in borderline leprosy. Br. J. Dermatol., 150: 570-574. http://cat.inist.fr/?aModele $=$ afficheN\&cpsidt $=15587043$

12. Waters, W.R., M.V. Palmer, D.L. Whipple, M.P. Carlson and B.J. Nonnecke, 2003. Diagnostic implications of antigen-induced gamma interferon, nitric oxide and tumor necrosis factor alpha production by peripheral blood mononuclear cells from mycobacterium bovis-infected cattle. Clin. Diagn. Lab. Immunol., 10: 960-966. DOI: 10.1128/CDLI.10.5.960-966.2003

13. Rook, G.A., 1988. The role of vitamin D in tuberculosis. Am. Rev. Respir. Dis., 138: 768-770. http://www.ncbi.nlm.nih.gov/pubmed/2849343

14. Rockett, K.A., R. Brookes, I. Udalova, V. Vidal, A.V. Hill and D. Kwiatkowski, 1998. 1,25Dihydroxyvitamin D3 induces nitric oxide synthase and suppresses growth of mycobacterium tuberculosis in a human macrophage-like cell line. Infect. Immunol., 11: 5314-5321. http://iai.asm.org/cgi/content/abstract/66/11/5314

15. Koeffler, H.P., H. Reichel, J.E. Bishop and A.W. Norman, 1985. Gamma-interferon stimulates production of 1,25-dihydroxyvitamin D3 by normal human macrophages. Biochem. Biophys. Res. Commun., 127: 596-603. http://www.ncbi.nlm.nih.gov/pubmed/3919734

16. Rook, G.A., J. Steele, L. Fraher, S. Barker, R. Karmali and J. O'Riordan et al., 1986. Vitamin D3, gamma interferon and control of proliferation of mycobacterium tuberculosis by human monocytes. Immunology, 57: 159-163. http://www.pubmedcentral.nih.gov/articlerender.fc gi artid $=1453883$ 
17. Waters, W.R., B.J. Nonnecke, M.V. Palmer, S. Robbe-Austermann, J.P. Bannantine and J.R. Stabel et al., 2004. Use of recombinant ESAT6: CFP-10 fusion protein for differentiation of infections of cattle by mycobacterium bovis and by M. avium subsp avium and $M$. avium subsp paratuberculosis. Clin. Diagn. Lab. Immunol., 11: 729-735. DOI: 10.1128/CDLI.11.4.729-735.2004

18. Waters, W.R., M.V. Palmer, B.J. Nonnecke, D.L. Whipple and R.L. Horst, 2004. mycobacterium bovis infection of vitamin Ddeficient NOS2-/-mice. Microb. Pathog., 36: 11-17. DOI: 10.1016/j.micpath.2003.08.008

19. Buddle, B.M., D.N. Wedlock, N.A. Parlane, L.A. Corner, G.W. De Lisle and M.A. Skinner, 2003. Revaccination of neonatal calves with mycobacterium bovis BCG reduces the level of protection against bovine tuberculosis induced by a single vaccination. Infect. Immunol., 71: 6411-6419. DOI: 10.1128/IAI.71.11.6411-6419.2003

20. Shi, L., Y.J. Jung, S. Tyagi, M.L. Gennaro and R.J. North, 2003. Expression of Th1-mediated immunity in mouse lungs induces a mycobacterium tuberculosis transcription pattern characteristic of nonreplicating persistence. Proc. Natl. Acad. Sci. USA., 100: 241-246. DOI: 10.1073/pnas.0136863100

21. Weatherby, K.E., B.S. Zwilling and W.P. Lafuse, 2003. Resistance of macrophages to mycobacterium avium is induced by alpha2adrenergic stimulation. Infect. Immunol., 71: 22-29. DOI: 10.1128/IAI.71.1.22-29.2003

22. Bafica, A., C.A. Scanga, C. Serhan, F. Machado, S. White and A. Sher et al., 2005. Host control of mycobacterium tuberculosis is regulated by 5lipoxygenase-dependent lipoxin production. J. Clin. Invest., 115: 1601-1606. DOI: 10.1172/JCI23949

23. Hibbs, Jr. J.B., 1991. Synthesis of nitric oxide from L-arginine: A recently discovered pathway induced by cytokines with antitumour and antimicrobial activity. Res. Immunol., 142: 565-569. http://cat.inist.fr/?aModele=afficheN\&cpsidt=5083709

24. Adams, L.B., S.G. Franzblau, Z. Vavrin, J.B. Hibbs, Jr. and J.L. Krahenbuhl, 1991. L-arginine-dependent macrophage effector functions inhibit metabolic activity of mycobacterium leprae. J. Immunol., 147: 1642-1646.

http://www.jimmunol.org/cgi/content/abstract/147/5/1642

25. Kroncke, K.D., K. Fehsel and V. Kolb-Bachofen, 1998. Inducible nitric oxide synthase in human diseases. Clin. Exp. Immunol., 113: 147-156. DOI: 10.1046/j.1365-2249.1998.00648.x
26. Brown, N., M. Jacobs, S.K. Parida, T. Botha, A. Santos and L. Fick et al., 2005. Reduced local growth and spread but preserved pathogenicity of a deltapurC mycobacterium tuberculosis auxotrophic mutant in gamma interferon receptor-deficient mice after aerosol infection. Infect. Immun., 73: 666-670. http://www.ncbi.nlm.nih.gov/pubmed/15618214

27. Rhee, K.Y., H. Erdjument-Bromage, P. Tempst and C.F. Nathan, 2005. S-nitroso proteome of mycobacterium tuberculosis: Enzymes of intermediary metabolism and antioxidant defense. Proc. Natl. Acad. Sci. USA., 102: 467-472. DOI: 10.1073/pnas.0406133102

28. Flynn, J.L. and J. Chan, 2003. Immune evasion by Mycobacterium tuberculosis: Living with the enemy. Curr. Opin. Immunol., 15: 450-455. DOI: 10.1016/S0952-7915(03)00075-X

29. Waters, W.R., B.J. Nonnecke, T.E. Rahner, M.V. Palmer, D.L. Whipple and R.L. Horst, 2001. Modulation of mycobacterium bovis-specific responses of bovine peripheral blood mononuclear cells by 1 , 25-dihydroxyvitamin $\mathrm{D}(3)$. Clin. Diagn. Lab. Immunol., 8: 1204-1212. DOI: 10.1128/CDLI.8.6.1204-1212.2001

30. Huttunen, K., J. Pelkonen, K.F. Nielsen, U. Nuutinen, J. Jussila and M.R. Hirvonen, 2004. Synergistic interaction in simultaneous exposure to streptomyces californicus and stachybotrys chartarum. Environ. Health Perspect., 112: 659-665. http://www.ehponline.org/members/2004/6701/670 1.html

31. Gretzer, C., P. Thomsen, 2000. Secretion of IL-1 and $\mathrm{H} 2 \mathrm{O} 2$ by human mononuclear cells in vitro. Biomaterials, 21: 1047-1055.

http://www.ncbi.nlm.nih.gov/entrez/query.fcgi?cmd=Ret rieve $\& \mathrm{db}=$ PubMed $\&$ dopt $=$ Citation $\&$ list_uids $=10768757$

32. Rhoades, E.R., I.M. Orme, 1997. Susceptibility of a panel of virulent strains of mycobacterium tuberculosis to reactive nitrogen intermediates. Infect. Immunol., 65: 1189-1195. http://iai.asm.org/cgi/content/abstract/65/4/1189

33. Steel, R.G.D. and J.H. Torrie, 1980. Principles and Procedures of Statistics: A Biometrics Approach. 2nd Edn., McGraw-Hill, New York, pp: 633.

34. Cantorna, M.T., C.E. Hayes and H.F. DeLuca, 1996. 1,25-Dihydroxyvitamin D3 reversibly blocks the progression of relapsing encephalomyelitis, a model of multiple sclerosis. Proc. Natl. Acad. Sci. USA., 93: 7861-7864. http://www.pnas.org/content/93/15/7861.abstract

35. Provvedini, D.M., C.D. Tsoukas, L.J. Deftos and S.C. Manolagas, 1983. 1, 25-dihydroxyvitamin D3 receptors in human leukocytes. Science, 221: 1181-1183. DOI: 10.1126/science.6310748 
36. Brennan, A., D.R. Katz, J.D. Nunn, S. Barker, M. Hewison and L.J. Fraher et al., 1987. Dendritic cells from human tissues express receptors for the immunoregulatory vitamin D3 metabolite, dihydroxycholecalciferol. Immunology, 61: 457-461. http://www.pubmedcentral.nih.gov/articlerender.fc gi? artid=1453440

37. Topilski, I., L. Flaishon, Y. Naveh, A. Harmelin, Y. Levo and I. Shachar, 2004. The antiinflammatory effects of 1,25-dihydroxyvitamin D3 on Th2 cells in vivo are due in part to the control of integrin-mediated $\mathrm{T}$ lymphocyte homing. Eur. J. Immunol., 34: 1068-1076. DOI: 10.1002/eji.200324532

38. Wittke, A., V. Weaver, B.D. Mahon, A. August and M.T. Cantorna, 2004. Vitamin D receptordeficient mice fail to develop experimental allergic asthma. J. Immunol., 173: 3432-3436. http://www.jimmunol.org/cgi/content/abstract/173/ $5 / 3432$

39. Firmani, M.A. and L.W. Riley, 2002. mycobacterium tuberculosis CDC1551 is resistant to reactive nitrogen and oxygen intermediates in vitro. Infect. Immunol., 70: 3965-3968. DOI: 10.1128/IAI.70.7.3965-3968.2002
40. Flynn, J.L. and J. Chan, 2001. Tuberculosis: Latency and reactivation. Infect. Immun., 69: 4195-201. DOI: 10.1128/IAI.69.7.4195-4201.2001

41. Jagannath, C., J.K. Actor and Hunter R.L. Jr., 1998. Induction of nitric oxide in human monocytes and monocyte cell lines by mycobacterium tuberculosis. Nitric Oxide, 2: 174-186. DOI: 10.1006/niox.1998.9999

42. Stuehr, D.J., C.C. Wei, Z. Wang and R. Hille, 2005. Exploring the redox reactions between heme and tetrahydrobiopterin in the nitric oxide synthases. Dalton Trans., 21: 3427-3435. DOI: 10.1039/b506355h

43. Roy, S., S. Sharma, M. Sharma, R. Aggarwal and M. Bose, 2004. Induction of nitric oxide release from the human alveolar epithelial cell line A549: An in vitro correlate of innate immune response to mycobacterium tuberculosis. Immunology, 112: 471-480. http://www.ncbi.nlm.nih.gov/pubmed/15196216 